\title{
On the role of Susanna in Susanna: A Greimassian contribution
}

\begin{tabular}{|c|c|}
\hline \multicolumn{2}{|c|}{$\begin{array}{l}\text { Authors: } \\
\text { Dichk M. Kanonge }{ }^{1} \\
\text { Pierre J. Jordaan }{ }^{1}\end{array}$} \\
\hline \multicolumn{2}{|c|}{$\begin{array}{l}\text { Affiliations: } \\
{ }^{1} \text { Faculty of Theology, } \\
\text { North-West University, } \\
\text { Potchefstroom Campus, } \\
\text { South Africa }\end{array}$} \\
\hline \multicolumn{2}{|c|}{$\begin{array}{l}\text { Note: } \\
\text { This article is part of the } \\
\text { author's post-doctoral } \\
\text { studies at the North-West } \\
\text { University, under the } \\
\text { supervision of Prof. Pierre } \\
\text { Jordaan. }\end{array}$} \\
\hline \multicolumn{2}{|c|}{$\begin{array}{l}\text { Correspondence to: } \\
\text { Dichk Kanonge }\end{array}$} \\
\hline \multicolumn{2}{|c|}{$\begin{array}{l}\text { Email: } \\
\text { dickmwamba@yahoo.fr }\end{array}$} \\
\hline \multicolumn{2}{|c|}{$\begin{array}{l}\text { Postal address: } \\
\text { Private Bag X6001, } \\
\text { Potchefstroom 2520, } \\
\text { South Africa }\end{array}$} \\
\hline \multicolumn{2}{|c|}{$\begin{array}{l}\text { Received: } 28 \text { Mar. } 2013 \\
\text { Accepted: } 27 \text { June } 2013 \\
\text { Published: } 30 \text { June } 2014\end{array}$} \\
\hline \multicolumn{2}{|c|}{$\begin{array}{l}\text { How to cite this article: } \\
\text { Kanonge, D.M. \& Jordaan, } \\
\text { P.J, 2014, 'On the role of } \\
\text { Susanna in Susanna: A } \\
\text { Greimassian contribution', } \\
\text { HTS Teologiese Studies/ } \\
\text { Theological Studies 70(3), } \\
\text { Art. \#1971, } 7 \text { pages. http:// } \\
\text { dx.doi.org/10.4102/hts. } \\
\text { v70i3.1971 }\end{array}$} \\
\hline \multicolumn{2}{|c|}{$\begin{array}{l}\text { Copyright: } \\
\text { C 2014. The Authors. } \\
\text { Licensee: AOSIS } \\
\text { OpenJournals. This work } \\
\text { is licensed under the } \\
\text { Creative Commons } \\
\text { Attribution License. }\end{array}$} \\
\hline \multicolumn{2}{|l|}{ Read online: } \\
\hline 口prida & $\begin{array}{l}\text { Scan this QR } \\
\text { code with your } \\
\text { smart phone or } \\
\text { mobile device } \\
\text { to read online. }\end{array}$ \\
\hline
\end{tabular}

This article addresses the highly disputed distribution of roles in the story of Susanna. Susanna consists of a number of actors of whom only a few such as Susanna, the two elders, the Jewish people and Daniel are directly related to the central action of the story. With regard to the roles of these actors in the story however, a question arises: Who is the subject of the story of Susanna? Most scholars question the attribution of the role of subject to Susanna. Their contention however, has not yet been sustained by convincing evidence stemming from the use of a suitable method. This study attempts to fill this gap by using the Greimassian approach to narratives, as refined by Everaert-Desmedt. The approach comprises three levels of analysis: the figurative, the narrative and the thematic. The contribution focuses only on the narrative level of analysis, particularly on the actantial model because the main role of this structure is to reveal different functions of actors called here actants. It is the contention here that following the actantial model of the Greimassian approach of analysis, Susanna emerges as the subject of the main concern of the story.

\section{The problem}

Susanna ${ }^{1}$ is a short story and short stories consist of 'a limited number' of actors (Henry 1991:106107). The actors here are Joachim, Susanna, Susanna's father and mother, the two elders, God, the Jewish people, Susanna's maids, Joachim's household servants, Susanna's children, the fictive young man, the unnamed daughters of Israel, Daniel and the angels. With regard to the roles that these actors play in the story however, questions arise. And the most disputed question is the following: Who is the subject of the story? Most scholars contest the attribution of the role of subject to Susanna. ${ }^{2}$ They would agree with Levine (2004:311) that 'Susanna is not (first and foremost) subject, she is object. And she is abject.'

It is on this contention of Levine that this investigation seeks to focus. In fact, Levine assumes that Susanna is the object but does not explain what it means from her point of view, to be the subject or the object of a story. Since no scholar has as yet replied to Levine in defence of the alternative view and her contention has never been supported by clear evidence, this article attempts to fill the gap by providing grounds for establishing Susanna as the subject of the story. The study follows the Greimassian approach focusing on the narrative analysis in general and the actantial model in particular, as outlined below. In fact, as will be revealed shortly, the actantial model serves to reveal roles of actants.

In the Greimassian approach, a distinction is made between a sentential subject (subject of a sentence) and a discursive subject (a subject of a discourse) (Greimas \& Courtés 1979:369-371). This study deals with the discursive subject in Susanna.

Since it is accepted that verse 5 constitutes the topic sentence of Susanna (cf. Kanonge 2010), it is consequently assumed here that the preservation of the Law of Moses is the main concern, the object of the story of Susanna. Accordingly, the main actantial model of the story is considered. It is the contention here that following the actantial model, Susanna emerges as the actant, mostly concerned with the obedience to the Law and thus the subject of the story.

\section{The approach of analysis}

As said above, this study uses the narrative step of the Greimassian approach to determine the subject of Susanna. In fact, the narrative level of analysis examines the organisation of the text as discourse. It consists of the actantial model and the narrative syntax. Here however, as mentioned above, only the actantial model is explored. In fact, this mechanism provides a new perspective of

1.The apocryphal story of Susanna is an addition found at the end of the Greek book of Daniel in the LXX (cf. ch. 13). In this study, Susanna (italicised) refers to the story of Susanna whilst Susanna (non-italicised) refers to its female protagonist.

2.The text of Susanna that will be used here is essentially the Theodotion version. This version has a most elaborate narrative focussing more on Susanna than the LXX does. The LXX Greek text is quoted from Rahlfs's (1996) edition of the LXX. 
the character (Pavis, Chantz \& Carlso 1998:469) by revealing different functions and activities performed in a narrative by actants (Neemann 1999:126). This tool of analysis is now summarily considered.

\section{The actantial model}

The actantial model is the best known and the most quoted element of Greimas's theory (Czamiauska-Joerges \& Gagliardi 2003:41). The main role of the actantial model is to reveal different functions of actants in a narrative (Neemann 1999:126). According to Tesnière (cf. Greimas \& Courtés 1979:3), an actant is what produces or undergoes an action and is different from a character. Characters belong to the figurative level (which will not be dealt with here) whilst actants belong to the narrative analysis. An actant can be a human being, an abstraction, a collective character or an animal (Greimas 1976:96). A character can assume different actantial functions. An actant is an antactant when his action is opposing the action of another actant. Greimas's actantial model consists of six actants, namely: the subject, the object, the addresser (sender), the addressee (receiver), the helper and the opponent (Ubersfeld 1999:37-40). The Greimassian actantial model is now considered.

\section{The structure of the actantial model}

The driving philosophy behind the Greimassian actantial model (Kanonge 2010:46) is the contention that a story gives an account of the quest of a subject for an object (axis of desire). The quest for the object is communicated to an addressee by an addresser (axis of communication); a helper assists the subject in his pursuit whilst an opponent opposes his mission (axis of power). In other words, as will be revealed shortly, the actantial model consists of six actants featuring on three main axes: the axis of desire, the axis of communication and the axis of power. The main relations between actants in a narrative can be structured as seen in Figure 1.

The following section examines relations between actants in a narrative.

\section{Relations between actants in a narrative}

As said above, these six actants are organised in three couples on three axes which are discussed in the following paragraph.

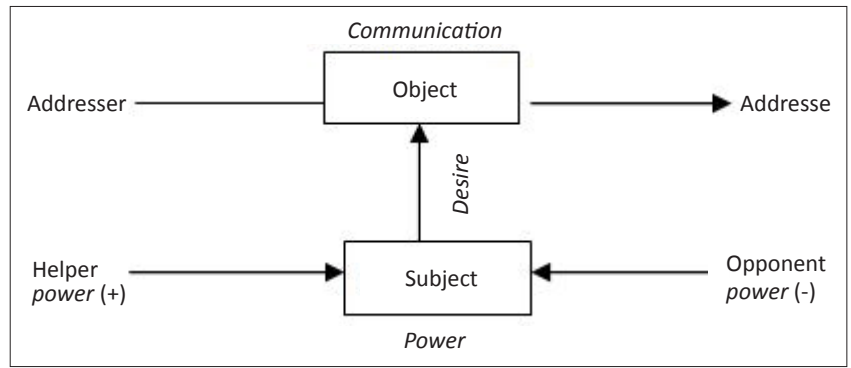

Source: Greimas cited in Ubersfeld, A., 1999, Reading theatre, University of Toronto Press, Toronto

FIGURE 1: Actantial model illustrating different relationships between actants in a narrative.
The axis of desire: The relation between subject and object: The subject and the object are the sine qua none of every narrative (Hénault 1983:46). Their relation is placed on the axis of desire. In other words, the course of a narrative is the description of the quest of the subject for the object (EveraertDesmedt 2007:40). All other functions in a narrative are determined by their relation to the subject and the object (Hénault 1983:48). Types of relations between the subject and the object on the one hand and the coexistence of many subjects in narratives on the other are considered below:

- Types of relations between the subject and the object: The relation between the subject and the object is called a narrative utterance. A narrative utterance can be either an utterance of state (stipulating that the subject is either in conjunction with the subject or not) or an utterance of doing (denoting the attempt of the subject to be in conjunction with the object or indicating the transition from one state to another).

- There are two types of utterances of state: the conjunctive utterance of state (stating that the subject is in conjunction with the object: $\mathrm{S} \Lambda \mathrm{O}$ ) and the disjunction utterance of state (stating that the subject is not in conjunction with the object: SVO).

- The transition from one state to another or vice versa implies a transformation in terms of the utterance of doing which requires the intervention of a subject of doing (or a subject operator) and can be written as follows: $[\mathrm{S} 1 \mathrm{VO} \longrightarrow[\mathrm{S} 1 \Lambda \mathrm{O}]$.

According to this formula, the subject (S1) was first separated from the object $(\mathrm{O})$ but is afterwards conjoined to it by an intermediary transformation. The transformation is caused by a transforming doing F (Faire transformateur in French) of an operator meta-subject S2: $\mathrm{F}_{\text {(transformation) }}[\mathrm{S} 2 \longrightarrow(\mathrm{S} 1 \Lambda \mathrm{O})]$.

This reads: S2 causes S1 to be in conjunction with the object. $\mathrm{S} 2$ is a subject operator and S1 is a subject of state. If S2=S1 there is a reflexive doing but if $\mathrm{S} 2 \neq \mathrm{S} 1$ there is a transitive doing:

- Anti-subjects: In many cases there are two or more subjects $\left(\mathrm{S}_{\mathrm{A}^{\prime}}, \mathrm{S}_{\mathrm{B}}\right)$, with opposing quests in a narrative. In this case, there is a subject and an anti-subject. An antisubject is a subject $\left(\mathrm{S}_{\mathrm{A}}\right)$ who, in order to reach the object of his quest $\left(\mathrm{O}_{\mathrm{A}}\right)$, must frustrate the object of quest $\left(\mathrm{O}_{B}\right)$ of another subject $\left(\mathrm{S}_{\mathrm{B}}\right)$. Anti-subjects appear in narratives in three different ways (Everaert-Desmedt 2007:42-43):

- Two (or more) subjects $\left(\mathrm{S}_{\mathrm{A}}\right.$ and $\mathrm{S}_{\mathrm{B}}$ ) compete to obtain the same object $\left(\mathrm{O}_{\mathrm{A}}=\mathrm{O}_{B}\right)$. The success of $\mathrm{S}_{\mathrm{A}}$ means the failure of $S_{B^{\prime}}$ as illustrated in Figure 2.

A good illustration of this can be found in chapter 2 of the book of Esther. She is prepared to ascend to the throne by getting married to the king. The goal of her marriage is to secure a place in the empire for her people. However, there are many candidates but only one of them will become queen:

- Two subjects $\left(\mathrm{S}_{\mathrm{A}}\right.$ and $\left.\mathrm{S}_{\mathrm{B}}\right)$ take each other as objects: The success of one is the failure of the other. This scenario can be illustrated as in Figure 3. 


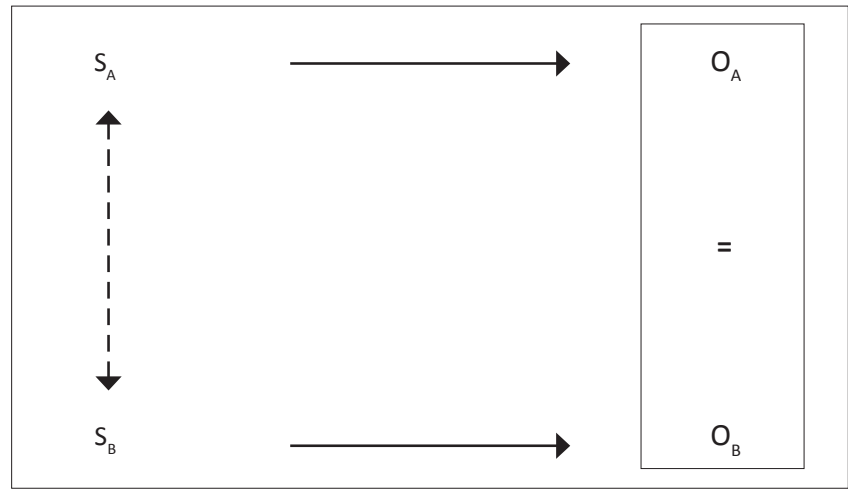

Source: Everaert-Desmedt, N., 2007, Sémiotique du Récit, De Boeck, Bruxelles FIGURE 2: Illustration of two subjects competing for one object in a narrative.

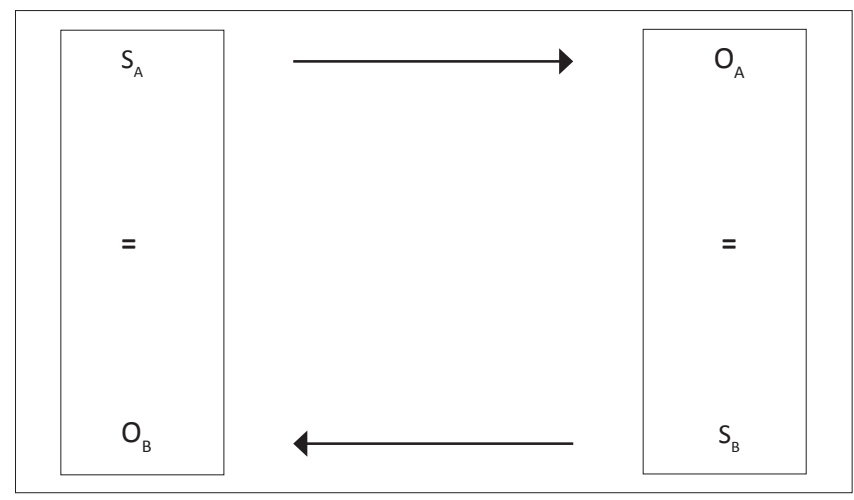

Source: Everaert-Desmedt, N., 2007, Sémiotique du Récit, De Boeck, Bruxelles FIGURE 3: Illustration of two subjects taking each other as object in a narrative.

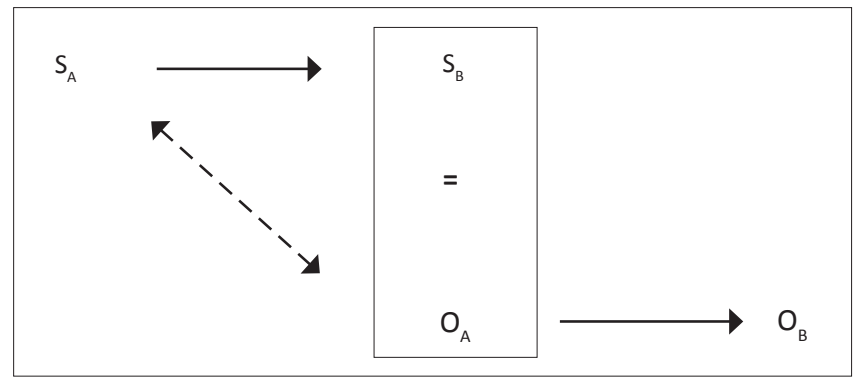

Source: Everaert-Desmedt, N., 2007, Sémiotique du Récit, De Boeck, Bruxelles FIGURE 4: A subject taking another subject as his object.

The story of David and Goliath (1 Sm 17) offers a good example in this case. David's and Goliath's lives are at stake. The death of either David or Goliath implies that his people become slaves and have to worship the deity of the victorious one:

- A subject $\left(\mathrm{S}_{\mathrm{A}}\right)$ takes as object $\left(\mathrm{O}_{\mathrm{A}}\right)$ another subject $\left(\mathrm{S}_{\mathrm{B}}\right)$ who pursues another object $\left(\mathrm{O}_{\mathrm{B}}\right)$. In engaging in the pursuit of another object $\left(\mathrm{O}_{B}\right)$, the subject $S_{B}$ refuses to be the object of $S_{A}$ and therefore is opposed to the quest of $S_{A}$. This model can be represented in Figure 4 .

The story of Susanna and the elders is modelled on this scenario. Two conflicting quests are evident. The two elders aim to have intercourse with all beautiful women (Susanna $19,56 \& 57)$ but Susanna is striving to please God and not to sin against him (Susanna 2, 3 \& 23).
In each narrative the actantial roles of subject or anti-subject depend on the type of relationship between an actant with the object of the story, its central concern. A subject is characterised by his positive longing for the object whilst an anti-subject is negatively linked to the object.

The axis of communication: Addresser and addressee: The second couple of actants is the bond between the addresser (also known as sender) and the addressee (also called receiver). As Tochon (2002:52) puts it, 'the sender is the person (or feature, or event) responsible for initiating the quest; the receiver is the actant for whose benefit the quest is undertaken.' The addresser imparts the object to the addressee and the addressee may or may not accept it. The mission of the addresser includes three main roles (EveraertDesmedt 2007:47):

- The addresser's first role is to transmit the importance of the object to the potential subject. The communication of the object takes the form of the narrative utterance (énoncé narratif): Addresser $\longrightarrow$ object $\longrightarrow$ Addressee.

The schema indicates the attempt of the addresser to create the need for the object in the subject. For this reason, the addresser is called subject of state, for he longs for the object.

- The addresser is also said to be a subject manipulator: Addressers do not act themselves directly, but they make subjects act, by transmitting modalities to them for the acquisition of the object. Modalities consist of transmitting knowledge about the object, or a duty to provoke the want (devoir) of the addressee.

- The addresser represents values that come into play in a narrative. This actant can judge the action accomplished by the subject operator. For this reason the addresser is called subject adjudicator.

The axis of power: Helper and opponent: The last couple acts on the subject, either to help them reach their goal or distract them from it (Groupes d'Entrevernes 1977:21). An anti-subject is always an opponent but every opponent is not always an anti-subject (Everaert-Desmedt 2007:52).

\section{The analysis}

As eluded to above, this article deals with the attribution of roles in Susanna using the Greimassian approach, mainly the actantial model of the narrative analysis of Susanna. This above-described approach is now applied to the story of Susanna.

\section{The actantial organisation of the story of Susanna}

The study of the actantial organisation of Susanna will focus on the configuration of the actantial of Susanna and the relations between actants and antactants in the story. The configuration of the actantial model of Susanna is now considered below.

\section{The configuration of Susanna's actantial model}

As said above, the actantial model of Susanna is based on the contention that verse 5 is the topic sentence of the 
story and thus the Law is the main concern of the story. The story is designed to deal with wickedness, specifically 'sexual perversion', in the Babylonian Jewish community (Harrington 1999:114). The importance of the issue is that sexual immorality in the Jewish axiology is one of the three sins (others two being idolatry and eating pork) to be avoided even at the cost of one's life (Kanonge 2010:101; cf. Harrington 1999:114; Mackenzie quotes from Moore 1977:91). In other words, the story aims to persuade Jews to stick to the Law and resist wickedness. It is remarkable that this main programme appears as a reaction to another programme inspired by Babylon, which aims to introduce wickedness into the Jewish community. Therefore, Susanna has a dual actantial organisation. It has actants and antactants, as the following investigation shows. There is an object (the Law, championed by Susanna) and anti-object (wickedness, the rejection of the Law championed by the two elders), an addresser (God v. 5) and anti-addresser (Babylon v. 5) and a subject (Susanna) with a dual anti-subject (the two elders). The main actantial model focuses on God as addresser, the Law as the object and Susanna as the subject. A second opposing actantial model can be designed, focusing on Babylon as addresser, wickedness as object and the elders as subject.

The main actantial organisation of the story focuses on the Law as main object of quest (the main concern of the story) as said above and the configuration can be seen in Figure 5.

According to the chart in Figure 5, in accordance with verse verse 5 as said above, the Law, as symbol of Jewishness (Kanonge 2010:186) is the unique object of value in the narrative worth dying for.

The centrality of the Law defines all relations and roles of actants. By declaring that 'the Lord said that wickedness has come from Babylon' (v. 5), the narrator assumes that God attracts the attention of Jews to the importance of the Law. The actant whose role is to underline the importance of the object is the addresser. Therefore, God is the addresser in this structure.

Susanna exemplifies the unfailing longing for the maintenance of the Law. In fact, she is even willing to give her life to remain faithful to the Lord (v. 23). The actant whose function is the pursuit of the object is the subject. Susanna is therefore a subject in this structure. However, Susanna's commitment to the Law runs against the elders' wickedness. The two elders are the opponents to her action. The relations between actants are examined below.

\section{Relations between actants and antactants in Susanna}

Susanna is a canonical narrative when considered from the Greimassian approach of analysis. In the Greimassian approach, a canonical story as described above comprises three axes defining different relationships between six actants. The above analysis shows that all six actants of the Greimassian model and their antactants are identifiable in the story. The main actants featuring in the story of Susanna are considered below focusing specifically on the subject.

Addresser and addressees: From the Jewish perspective, God is the addresser, as argued above. In fact, the story starts with a word of the Lord (v. 5, o $\delta \varepsilon \sigma \pi$ ó $\eta \varsigma)$ and ends with praise to God (v. 60). God is one of the most prominent actants in the story, and as the investigation will reveal shortly, God assumes all three traditional functions of the addresser. He appears in the story as a subject adjudicator, a subject manipulator and a subject of state.

God, as a subject of state, is different from the subject performer (also known as a subject operator). According to the story Susanna is the subject operator, directly concerned with the preservation of the Law in the story. There is no doubt that God has transmitted to Susanna his own appreciation of the Law. As a subject of state, God is concerned with the preservation of the Law in the Jewish community. His communication in verse 5 indicates his attempt to create the need for the maintenance of the Law in Jews. The communication of the Lord to the Jewish people can be seen in Figure 6.

Figure 6 is a narrative utterance as said above. This narrative utterance can take the following configuration: God $\longrightarrow$ (Jews $\Lambda$ the Law).

Based on verse 5, this narrative utterance can read: 'God urges Jews to maintain the Law', to stick to their identity, to preserve their Jewishness. In fact, the story presents itself as a message of the Lord to Jews (v. 5).

Apart from verse 5, God does not appear directly in the story. Consequently, some scholars, like Gruen (2002:172), conclude that 'the Lord plays no role through most of the text.' This assumed absence of the Lord, however, is but a deliberate strategy of communication adopted by the story. In fact, God acts in accordance with his status as a subject manipulator. Manipulation denotes a remote action, but not disinterestedness. It should be noted, in accordance with the Greimassian tradition, that the word 'manipulation' is a

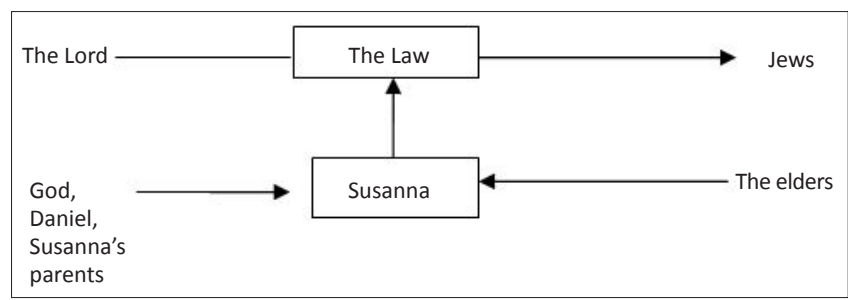

Source: Author's own work

FIGURE 5: The actantial model of Susanna focusing on Susanna as the subject with the Law as main object of quest in the narrative.

God $\longrightarrow$ The Law $\longrightarrow$ Jews

Source: Author's own work

FIGURE 6: God's communication of the importance of the Law to Jews. 
technical term hereafter. There is, of course, no connotation of dishonesty or deception as in the more popular usage of the term.

Manipulation denotes the action of the addresser on the addressee to make him act (faire faire). In this context it has to be understood as an integral part of 'causation'. Linguistically, the semantics of causation include direct and mediated causation, manipulation and direction, and coercion and permission (Kroeger 2004:204-208). The expression fairefaire [cause to do] characterises the causative action of the addresser on the future subject in accordance with the Greimassian approach to narrative. On the semiotic square, this expression opens four different modes of manipulation as seen in Figure 7 (Greimas \& Courtés 1979:220).

Intervention, obstruction, non-intervention and laissez faire (nonobstruction) characterise the action of the addresser.

Evidence from Susanna, suggests that God acts in accordance with these four aspects of manipulation and is mainly related to Susanna's action.

The statement $\dot{\varepsilon} \lambda \dot{\alpha} \lambda \eta \sigma \varepsilon v$ ó $\delta \varepsilon \sigma \pi$ ó $\rceil_{\varsigma}$ [the Lord said], as related above, highlights the intervention of the Lord in the model of the prophets of the Hebrew Bible (cf. Ellingworth \& Nida 1993:85-90). It is evident that this formula in Susanna highlights God's first intervention to make Jews conscious of the wickedness introduced by the elders. It is worth noticing that when wickedness appears God informs the Jews. His communication here is not purposeless. Verse 5 strives to push Jews into action; therefore, it is a faire faire [causing to do] evidencing of God's direct intervention. By naming God ó $\delta \varepsilon \sigma \pi$ ó $\rceil \zeta$, the narrator assumes that God supremely watches over the community. God's sovereignty does also emerge clearly from Susanna's prayer. God's knowledge of events even before their genesis (vv. 42-43) and his willingness to inform his people can have many implications (v. 5) here. There is an implication that God knew Susanna's movement in the garden as well as the elders' wickedness and their plot against Susanna. Besides, Susanna's refusal of the elders' proposal, her ensuing judgement and sentence to death could not escape his foreknowledge. Accordingly, God planned Daniel's intervention beforehand.

It is also evident here that other aspects of God's causation enter the play. Firstly, there is a non-intervention (ne pas fairefaire). God does not explicitly cause Susanna to go into the garden where the elders are hiding. Secondly, God does not stop Susanna from going out nor does he warn her of the presence of the elders in the garden (what he did with the community). There is a laissez faire, non-obstruction here. Laissez faire means leaving things to their own course without interfering. It does not mean disinterestedness.

In addition, after the evil judgement God does not allow Susanna's death. There is obstruction to the action (faire ne pas tuer [causing not to kill]). Until the end of the story, the community kills the two elders. God does not explicitly order

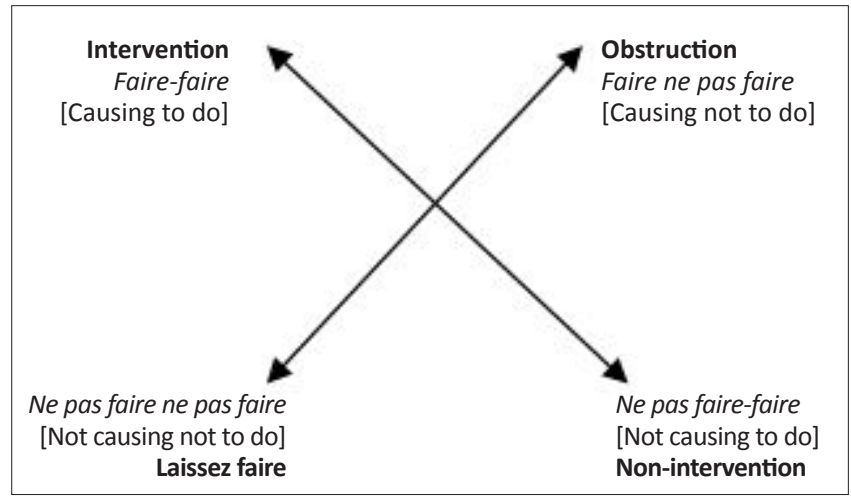

Source: Greimas, A.J., 1983, Du Sens II. Essais sémiotiques, Seuil, Paris

FIGURE 7: The four possible aspects of the manipulative action of the addresser on the addressee in a narrative.

the elders' killing. Neither does he object to it. Here again, there is, from God's initiative, a laissez faire [not causing not to do], non-obstruction.

What is important here is the factor that God's manipulative actions in the story are mostly related to Susanna rather than to other actants. This credits Susanna as the subject of the story. In fact, the subject of the story is that the actant, the addresser seeks to push to action.

As an addresser, God finally plays the role of an adjudicator. This function appears at the end of the narrative and corresponds to the phase of sanction. Normally, the sanction is the verdict of the addresser. He acts here as a subject adjudicator to acknowledge the accomplishment of the subject. Surprisingly, in this last episode of the story, God does not speak. However, he is the object of praise from the Jews because of his intervention on behalf of Susanna. Indirectly, their praise reveals that Susanna's achievement went according to norms established by God, namely the Law of Moses. The most important verdict, in accordance with Susanna's mission is: 'no shameful practice was found

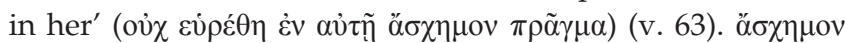
$(\pi \rho \tilde{\alpha} \gamma \mu \alpha)$ appears in Genesis 34:7 and Deuteronomy 24:1 with a sexual connotation (Bauer et al. 2000:147). According to

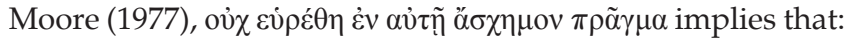

Susanna was not just found innocent of the act of adultery: her conduct was found above reproach, i.e. she had in no way encouraged the lecherous men or been responsible for their advances toward her. (p. 113)

As said above, however, God is not the only addresser in the story. There is an opposing addresser, or anti-addresser in the story, namely Babylon. The latter:

not only institutes a system of values that opposes the original quest but also attempt[s] to manipulate the receiver/subject to act in a way contrary to the desires of the first sender. (Martin \& Ringham 2000:25)

As a consequence, Jews undergo two opposing manipulative actions, respectively from the Lord and from Babylon. Babylon represents an ideology totally opposed to the traditional Jewish system of values centred on the Law of 
Moses. Rather, there is an attempt from each side to persuade. God strives to persuade Jews to keep the Law whilst Babylon offers an ideology based on a sexual licence. The two opposing systems of values can stand on the semiotic square as seen in Figure 8.

The decomposition of this schema gives the two possible main transformations in the story. Both transformations highlight the manipulative actions of addressers, namely God and Babylon, on the addressee (Jews including Susanna and the elders).

The function of transformation underlying God's action on Susanna appears as seen in Figure 9.

This function illustrates the result of God's manipulative action on Susanna at the end of the story. God succeeds in his endeavour to push Susanna to hold on to the Law until the end of the story.

On the other hand, Babylon's influence on the elders has the configuration shown above (see Figure 10).

This function represents the expected outcome of the manipulative action of Babylon on the elders. The aim of the action is to have the elders engage in sexual intercourse with Susanna and thus to overthrow the Mosaic regulation on sexuality (Law).

Figure 11 represents the confrontation of the two manipulative actions on Jews, at the end of the narrative.

As said above, God's endeavour succeeds at the expense of Babylon's attempt to dissuade Jews from keeping the Law with regard to chastity. Here again Susanna is the key player, the subject of the action, whilst the elders become a collective anti-subject.

Subject and object: The relation of the subject and/or the object, in Susanna, is complex. It does not only involve Susanna as the subject, but the elders as well. The object is again the Law, but apprehended differently. From Susanna's perspective, the main purpose is to maintain the Law. Her quest is commitment to the Law with regard to sexual regulation. On the other hand, however, the elders strive to reject the Law. Sexual freedom in general and sexual intercourse with Susanna in particular, is their main quest.

It is evident that there are two opposing quests with two opposing subjects in Susanna. The success of one is the failure of the other. Put together, the two quests can be represented as shown in Figure 12.

Susanna assumes two functions in this structure. She is the object of the elders' quest and she is herself a subject in the pursuit of the Law, the main object of the story.

The fact that Susanna is the object of the elders' quest is likely the reason why Levine assumes that she is not the subject of the story. Normally, the concept of the subject

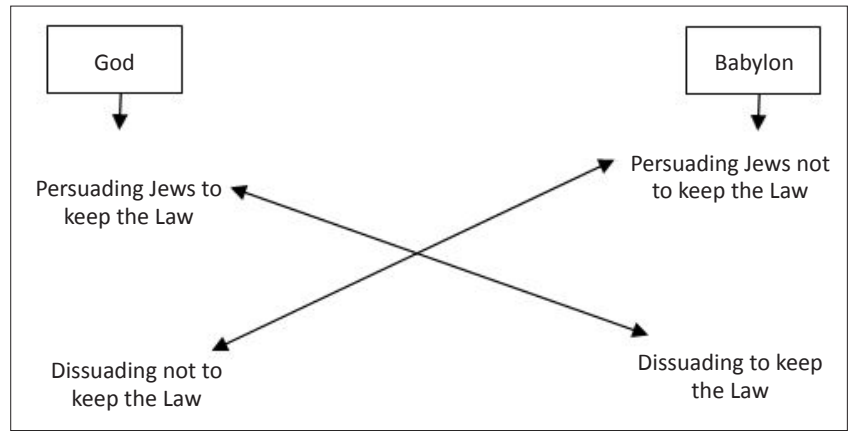

Source: Author's own work

FIGURE 8: The illustration of the twofold action of manipulation of Jews respectively by God and by Babylon.

$$
\mathrm{F}[\mathrm{God} \longrightarrow \text { (Susanna V Law)] }
$$

Source: Author's own work

FIGURE 9: The function of transformation underlying God's action on Susanna.

$$
\mathrm{F}[\text { Babylon } \longrightarrow \text { (the elders } \wedge \text { Susanna)] }
$$

Source: Author's own work

FIGURE 10: The function of transformation underlying Babylon's action on the elders.

F [Babylon $\longrightarrow$ (the elders V Susanna)]

Source: Author's own work

FIGURE 11: The function of transformation representing the confrontation of the respective twofold manipulative action of God and Babylon on Jews.

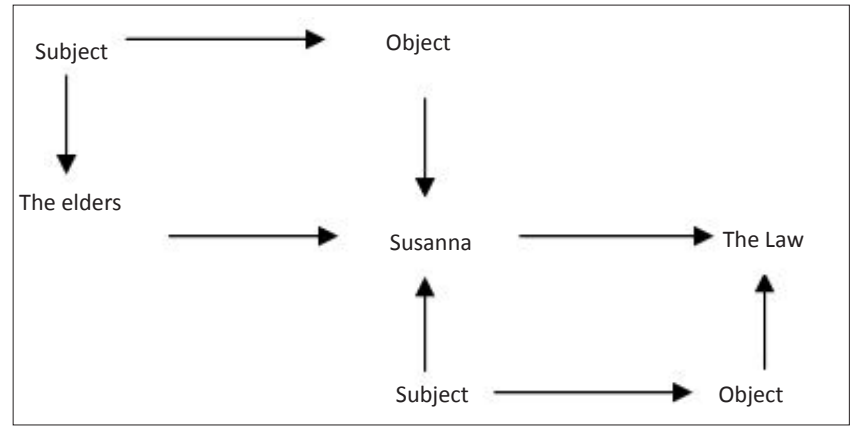

Source: Author's own work

FIGURE 12: Schema representing the two actantial roles of Susanna as object and subject in the narrative.

goes together with the concept of the object. In other words, Susanna can be subject only if she has an object of quest in the story. It is here where Levine contradicts herself. In fact, Levine rejects Garrard and Glancy's (cited in Levine 2004:313-314) allegations that Susanna's willingness to die reveals her fidelity to Joachim, her husband. According to her, 'Susanna's total fidelity is to the law of Israel, not to her husband' (Levine 2004:313-314, n. 5). Arguments between Garrard and Glancy, on the one hand, and Levine on the other, clearly indicate that Susanna has her own quest in the narrative. Striving to remain faithful to the Law or to her husband are quests. Consequently, there is no doubt here that Susanna is a subject in pursuit of the Law.

Moreover, being subject or object does not exclude one or the other. An actant can assume different actantial functions in 
a narrative (cf. Vance 1989:103). In Susanna, for example, the elders are dual subjects (from the Babylonian perspective) but they are also opponents. God is the addresser but he is also Susanna's helper (Kanonge 2010:135-137). Susanna and the elders are subjects in the narrative with different objects. The elders are anti-subject to Susanna (opposing her quest, her chastity) and Susanna is anti-subject to the elders (opposing their sexual perversion). Finally and most importantly, the subject of a narrative must be the actant in pursuit of the main object of the story. In the story of Susanna, the main object is the maintenance of the Law. Therefore, Susanna is the subject and the two elders are anti-subjects as they oppose the object of the story.

\section{Conclusion}

The endeavour of this study was to investigate the disputed distribution of roles in the story of Susanna. In fact, most scholars contest the attribution of the role of subject to Susanna. According to them, Susanna assumes only an actantial role of object in the story. Their assumptions however seem to be based only on mere prejudices. In fact it appears that no scholar has yet attempted to define the concepts of subject and object of a narrative. Consequently, it appears that the attribution of the role of object to Susanna is motivated by the assumption that the biblical view of women is fundamentally negative and thus all biblical stories about women must be interpreted accordingly. This way of reading biblical stories, based on preconceived ideas, may lack objectivity. It is imperative that valid conclusions result from the use of suitable methods. This article was aimed at filling this gap.

To address the above-mentioned contention, the narrative step of the Greimassian approach of analysis, mainly its actantial model, was followed. It was observed, from the distribution of actantial roles, that Susanna had a dual actantial configuration. Following verse 5 embodying the concern of the story, the preservation of the Law was singled out as the main quest. Opposed to this main quest was the elders' pursuit of wickedness. God was the addresser, the initiator of Susanna's quest. On the other hand, Babylon played an important role in inspiring wickedness in the elders. Unmistakably, the elders act as the enemies of the Law and subject of the opposing quest, they are antisubjects. Though being object of the elders' pursuit, Susanna exemplifies the unfailing longing for the maintenance of the Law, the main concern of the story. And as said above, an actant whose function is the pursuit of the main object is a subject. Therefore Susanna is the subject of the main concern of the story, the preservation of the Law.

\section{Acknowledgements Competing interests}

The author declares that he has no financial or personal relationship(s) that may have inappropriately influenced him in writing this article.

\section{Authors' contributions}

This article is part D.M.K's (North-West University) postdoctoral studies under the supervision of P.J.J. (North-West University).

\section{References}

Bauer, W., Danker, F.W., Arndt, W. \& Gingrich, F.W. (eds.), 2000, A Greek English lexicon of the New Testament and other early Christian literature, 3rd edn., University of Chicago Press, Chicago. http://dx.doi.org/10.7208/ chicago/9780226028958.001.0001

Czarniawska-Joerges, B. \& Gagliardi, P., 2003, Narratives we organize, John Benjamins Publishing Company, Amsterdam. http://dx.doi.org/10.1075/aios.11

Ellingworth, P. \& Nida, E.G., 1983, A translator's handbook on the letter to the Hebrews, United Bible Societies, London.

Everaert-Desmedt, N., 2007, Sémiotique du Récit, De Boeck, Bruxelles.

Greimas, A.J., 1976, Maupassant. La Sémiotique du Texte: Exercices Pratiques, Seuil, Paris.

Greimas, A.J., 1983, Du Sens II. Essais sémiotiques, Seuil, Paris

Greimas, A.J. \& Courtés, J., 1979, Sémiotique: Dictionnaire Raisonné du Langage, Hachette, Paris.

Groupes d'Entrevernes, 1977, Signes et Paraboles, Sémiotique et Texte évangélique, Seuil, Paris.

Gruen, E.S., 2002, Diaspora: Jews amidst Greeks and Romans, Harvard University Press, Cambridge.

Harrington, D.J., 1999, Invitation to the Apocrypha, Eerdmans Publishing Company, Grand Rapids.

Hénault, A., 1983, Narratologie Sémiotique Générale: Les enjeux de la Sémiotique, II, Presses Universitaires de France, Paris.

Henry, J.O., 1991, Wordsmiths: An approach to short story study, Maskew Miller Longman, Cape Town.

Kanonge, D.M., 2010, 'The emergence of women in the LXX Apocrypha: A semiotic study', PhD thesis, Department of Greek, North-West University.

Kroeger, P.R, 2004, Analyzing Syntax. A lexical-functional approach, Cambridge University Press, Cambridge. http://dx.doi.org/10.1017/СBO9780511801693

Levine, A., 2004, 'Hemmed in on every side: Jews and Women in the book of Susanna', in A. Brenner (ed.), Feminist Companion to Esther, Judith and Susanna, pp 303-323, T\&T Clark International, London.

Martin, B. \& Ringham, F., 2002, Dictionary of semiotics, Cassel, London.

Moore, C.A., 1977, Daniel, Esther and Jeremiah: The additions, Doubleday \& Company, Garden City.

Neemann, H., 1999, Piercing magic veil: Toward a theory of the Conte, Gunter Narr Verlag, Tübingen. (Biblio, 17).

Pavis, P., Chantz, C. \& Carlso, M. (eds.), 1998, Dictionary of the theatre: Terms, concepts, and analysis, University of Toronto Press, Toronto.

Rahlfs, A., 1996, Septuaginta: With morphology, Deutsche Bibelgesellschaft, Stuttgart.

Tochon, F.V., 2002, Tropics of teachings: Productivity, warfare and priesthood, University of Toronto Press, Toronto.

Ubersfeld, A., 1999, Reading theatre, University of Toronto Press, Toronto.

Vance, E., 1989, Marvelous signals: Poetics and sign theory in the Middle Ages, University of Nebraska Press, Lincoln. 